\title{
The Political Economy of Intellectual Property Rights: the Paradox of Article 27 Exemplified in Ghana
}

Martin de Beukelaer and Martin Fredriksson

The self-archived postprint version of this journal article is available at Linköping University Institutional Repository (DiVA):

http:/ / urn.kb.se/ resolve?urn=urn:nbn:se:liu:diva-152125

N.B.: When citing this work, cite the original publication.

This is an electronic version of an article published in:

Fredriksson, M., (2018), The Political Economy of Intellectual Property Rights: the Paradox of Article 27 Exemplified in Ghana, Review of African Political Economy, 45(157), .

https:// doi.org/ 10.1080/ 03056244.2018.1500358

Original publication available at:

https:/ / doi.org/ 10.1080/03056244.2018.1500358

Copyright: Taylor \& Francis (Routledge) (SSH Titles - no Open Select)

http:// www.routledge.com/ 


\title{
The Political Economy of Intellectual Property Rights: The Paradox of Article 27 exemplified in Ghana
}

\author{
Christiaan de Beukelaer \& Martin Fredriksson
}

\begin{abstract}
Orthodox copyright scholarship frames piracy in 'developing' countries as a detrimental and illegal practice that results from these countries' lack of economic, social and cultural development. They argue piracy needs to be discouraged, regulated, and finally overcome for legitimate business to flourish. In this paper, we challenge this viewpoint and question whether the implementation of international copyright instruments in legislation across Africa really promote those local economies or if it merely exposes them to neo-colonial exploitation. While the early international treatises on intellectual property rights (IPR) were formulated by European states and implemented in most part of Africa through colonial laws, more recent legislation has been globally implemented through institutions like the United Nations or the World Trade Organisations, which remain dominated by Western interests. Through a structured overview of IPRtreatises adoption in African countries we advance a political economy perspective of intellectual property rights as a (neo)colonial regime.
\end{abstract}

Keywords: piracy, Universal Declaration of Human Rights, Article 27, cultural rights, copyright, intellectual property rights

\section{Introduction}

The dominant discourse on copyright frames piracy in 'developing' countries as a destructive and illegal practice that results from these countries' lack of economic, social and cultural development. In this paper, we develop a critique of the implementation of international copyright instruments in local legislation. We do so by advancing a political economy perspective on the role of intellectual property rights (IPR), and particularly copyright, in Africa through an overview of international copyright treatises and their national implementations in African countries, juxtaposed to a more focused discussion of media piracy in Ghana. Ghana thus exemplifies the implications of piracy on the creative economy of an African country. This empirical discussion is theoretically contextualised as an exploration of the political economy of IPR in relation to cultural rights. 
We organise our argument around the tension between the two clauses of Article 27 of the Universal Declaration of Human Rights (UDHR):

(1) Everyone has the right freely to participate in the cultural life of the community, to enjoy the arts and to share in scientific advancement and its benefits.

(2) Everyone has the right to the protection of the moral and material interests resulting from any scientific, literary or artistic production of which he is the author. Universal Declaration of Human Rights, Article 27

The tension occurs between the different ways these two clauses of the same article can be read, rather than between the clauses as such. The Universal Declaration of Human Rights is the key document that outlines the global rights and obligations of citizens and states. The 'right to the protection of interests in intellectual property creations' is also recognised in Article 27(2) of the 1948 UDHR and Article 15(1)(c) of the 1966 International Covenant on Economic, Social, and Cultural Rights (ICESCR) (Yu 2007, 714). Yet, the explicit and extensive efforts of 'developed' countries to convince (if not to coerce) 'developing' countries to embrace 'good copyright citizenship' (MacNeill 2015) focus more on the implementation of a strict copyright regime than a fair balance between cultural rights and copyright. As this article aims to show, these regulations are imposed through an international trade regime embedded in a global political economy. By discussing their implementations within a human rights framework we hope to challenge the dominance of the international trade perspective in the contemporary IPRdiscourse and show that copyright is not only a trade issue but also a human rights issue. If the IPR-agenda primarily focuses on the issue of remuneration then the human rights perspective, encoded in the UDHR as well as in the The African Charter on Human and People's Rights, also emphasise the importance of cultural participation. To be clear, we do not argue against copyright protection per se, but stress the need to balance the economic right of exploitation with the right of access to culture.

The tensions we aim to unpack are both normative and geographical. The normative tension arises from the paradox inherent to Article 27, which creates a range of possible constellations between the protection and enforcement of intellectual property rights and cultural rights. The geographical tension arises from the significant power imbalances between different countries (in this case explored from the Ghanaian perspective), as a result of the inherently imbalanced political economy of IPR protection. This means that, in some cases, stricter copyright protection favours intellectual property rights over cultural rights and reinforces a political economy that is rooted in colonial history without 
consideration of social and power relations that significantly impact the basis on which ownership and participation is balanced. In exploring these tensions, we do not rally against the protection of intellectual property rights as such, but question how they can be better balanced with cultural rights. While some frame these tensions as inherently conflicting and others frame them as inherently co-existent (see below), we move beyond these polarities to give a more nuanced view on the role and implications of piracy in Ghana.

Our main aim is to find a better balance between the two sections of Article 27. We take a postcolonial approach to 'cultural rights', as one kind of human rights, and analyse how they relate to the extending realm of copyright protection and enforcement and its impact on the perception of piracy. We have done so in order to tilt the balance away from the primacy of copyright enforcement toward the primacy of the right to participate in culture. $^{\mathrm{i}}$

The remainder of this paper is organised as follows. First, it discusses the impact of media piracy in Ghana from an economic and empirical perspective. Second, it sets out the framework of our analysis: the political economy of copyright as a globally and historically situated regime. Third, it gives an overview of African signatories to conventions and agreements pertaining to the protection of intellectual property rights. On the basis of this overview, it discusses how the implementation of these documents reflects historical, colonial tensions in Africa. Fourth, it makes the case that the resolution in the tension between the two parts of Article 27 in the on-going fight against piracy lies in balancing cultural rights and copyrights. In conclusion, it address implications of theoretical and empirical engagement with 'postcolonial piracy' (Eckstein and Schwarz 2014a) for the balancing of Article 27.

\section{Everyday piracy in Ghana}

Copyright revenues across African countries are both limited and hard to gauge. There is a regulatory context that exists on paper, but it does not sufficiently nor adequately capture and reward the use of copyrighted works. Where collective management organisations (CMOs) exist, they do not always communicate their revenues, operating costs, and payments in a transparent and accountable manner. In 2013 the Ghanaian CMO, GHAMRO, supplied the Ghanaian Musicians' Union (MUSIGA) a round figure 
of $\mathrm{GH} \phi 700.000,00$ to estimate the contribution of royalties to the GDP of the country. This represents a mere $0.47 \%$ of the total calculated contribution of music $(\mathrm{GH} \not 149,644,983.00)$ to the GDP of the country (MUSIGA et al. 2015, 15). While these numbers illustrate GHAMRO's call for stronger enforcement, they also show the limited extent to which they are willing to give access to their books. GHAMRO has been founded, perhaps ironically so, to replace its state-run predecessor COSGA, following claims about the latter's lack of transparency and accountability. While the legislation and enforcement of copyright in relation to cultural rights is a global issue, this article focuses on the polarized approach in the context of African countries, where the tension between illicit activity and legal orthodoxy is very pronounced.

In March 2012, a joint action by the name "Operation Jail The Pirates" between GHAMRO, the Accra Metropolitan Police, and the Ghana Copyright Office, led to the arrest of 19 people during a raid of alleged music pirates at Kwame Nkrumah Circle, a busy traffic intersection and market place in Accra. In court, five of them were sentenced under the Ghanaian 2005 Copyright act to hefty fines. Due to lack of funds, the court defaulted on the fines and transformed their sentence into 2-year prison sentences (GhanaWeb 2012). GHAMRO were one of the driving forces behind this police and legal action. In their ostensible claim to 'clean up' illicit activity in music distribution, they have focused on suppressing piracy as opposed to integrating existing distribution mechanisms into the formal music economy. In 2013, they argued to be working towards a digital platform and licensing options for street vendors, no such structure is as of yet in place. Moreover, they are enforcing laws that the general public, including most pirates, does not necessarily understand (De Beukelaer 2015).

This case may seem trivial and anecdotal, though it does illustrate a long-standing structural issue around copyright in Ghana: discussions about legislation and enforcement lack nuance, as they are framed in terms of the all-encompassing destruction through piracy and the need for very tight copyright orthodoxy. The Ghanaian musicologist John Collins discusses this issue at some length when arguing that an attempt in 1987 of the Ghana Tape Recordists Association (GTRA) to license their cassette tape copying businesses with the National Phonogram Producers Union (NPPA) backfired when the Musicians Union of Ghana (MUSIGA), financially supported by the International Federation of Phonogram Industries (IFPI), opposed the agreement (Collins 2006, 161162). This well-documented case shows that the search for alternative models of licensing 
and copyright enforcement were opposed by major international players (IFPI), based on their strict reading of existing international IPR agreements.

Both the cases of 2012 and 1987 show that there is very limited leeway to discuss how IPR can - and should - be enforced. Rather than arguing that the issue is a Ghanaian one, related to its institutions, legislation, and enforcement (though that certainly matters too), there is a need to explore this tension as a political economy matter.

Enforcement efforts remain most explicitly oriented against those 'pirating' copyright content. Given the lack of a legally sound definition of piracy (Eckstein and Schwarz 2014b), it would go against the aim of this paper to make up a working definition; the notion of piracy is rather the contentious space between conflicting regimes of cultural and property rights and the limited enforcement of both. It is precisely this space that this paper aims to explore. As this paper illustrates, piracy can be a productive analytical concept that questions norms of authorship and ownership that are usually taken for granted and helps us understand how they are constructed and upheld.

The particular data, organisational structures, and issues differ across African countries. Yet the overall share of African countries in global copyright revenues is limited, in part because global data are scarce (they are not adequately measured and hence not featured in global industry reports). As the limited revenues occur in tandem with a weak regulatory (and sometimes legal) environment, it seems obvious to focus on better legislation and enforcement of copyright laws in order to stifle piracy and improve revenues. This would involve 'cleaning up' pirate practices, implementing law enforcement mechanisms, and the overall regulation of culture and media industries. This process is currently facilitated through collaborations between African CMOs and partner organisations in 'developed' countries. In Mali, BuMDA (Bureau Malien des Droits d'Auteurs) cooperates with its Japanese equivalent by way of development cooperation. In Ghana, GHAMRO has worked with NORCODE from Norway. These collaborations consist of workshops and capacity building. Our fieldwork data shows that foreign organisations with hardliner orthodox views on copyright have significantly influenced the GHAMRO leadership, thereby diminishing rather than increasing their willingness to explore alternative enforcement solutions. 
Since the early 2000s, there is an increased interest in the potential of cultural and creative industries to help diversify economies, strengthen exports, drive economic development, create jobs, etc. This interest is based in large part on key United Nations Conference on Trade and Development (UNCTAD) reports on the so-called creative economy (UNCTAD and UNDP 2008; UNCTAD and UNDP 2010). ${ }^{\text {ii }}$ These UN reports cite the informality and weak regulatory framework as problems that hamper the sector. Though interpretation of the role and importance of copyright legislation differs, empirical work in the Nigerian music and audio-visual industries suggests that informal economies and different forms of piracy might actually contribute to the development of local cultural industries (Lobato 2010; Larkin 2005; Larkin 2008).

Studies from different parts of the world indicate that piracy might be a productive force in 'developing' economies both in the sense that it caters to needs that are not satisfied by formal economies or the state, and because it creates innovations and business that can eventually find their ways into the formal economy (Sundaram 2009; Karaganis 2011). In the Ghanaian context, much like elsewhere across the continent, musicians accrue fame through media exposure and illicit music sales. In this context, their music is no longer the main product, their public visibility is. They trade this visibility as vehicle for brand and product marketing (see Shipley 2013). However, the difference between Ghana and Nigeria remains that the latter has a far larger population, meaning that domestic economic opportunities are immediately larger. Even so, the case for strict enforcement of orthodox copyright legislation is thus weaker than GHAMRO claims. Instead of fighting piracy it might be more productive for the local economy to find ways to integrate it in the legal economy.

\section{The Political Economy of International IPR}

A political economy perspective can help us understand the on-going attempts to impose and enforce a stricter copyright regime in Africa. In his book Copyrighting Culture from 1996, Roland Bettig uses political economy theory to analyse the global IPR regime as historically and socially situated structures and relations. Based on a series of empirical examples he discusses how contemporary media regulations, from national legislations to international IPR-treatises, contribute to the privatization of culture (Bettig 1996) Since Bettig published Copyrighting Culture a large body of critical copyright research has evolved that takes a similar approach to IPR without explicitly using a political 
economy perspective. Authors such as Lawrence Lessig (2004), James Boyle (1996; 2008), Eva Hemmungs Wirtén (2004), and Peter Drahos and John Braithwaite (2002) look at the expansion of IPR-regimes in relation to cultural expressions, software and biological substances as processes of commodification and enclosure in contemporary capitalism. Here the holistic and historicizing perspective that is central to political economy (Golding and Murdock 1997) forms the basis for a critical analysis of IPR. Although much of this research focuses on Euro-American conditions it also contributes to highlighting the global power structures that underlie the local implementation of international IPR-regimes, for instance by critically examining how international treatises on IPR maintain colonial legacies that perpetuate global inequalities.

This article focuses on the African implementation of some of the most important of those treatises and declarations: the Berne Convention of 1886; the Universal Copyright Convention (UCC) adopted by the UN in 1956; the WIPO Copyright treaty (WTC) and the WIPO Performance and Phonograms Treaty (WPPT) adopted by the UN World Intellectual Property Rights Organisation (WIPO) in 1996, and WTO's agreement on Trade-Related Aspects of Intellectual Property Rights (TRIPS) of 1994. In order to give a more balanced account of the development of IPR we also include human rights instruments, namely the 1981 African Charter on Human and Peoples' Rights; the 1948 Universal Declaration of Human Rights (UDHR), and the 1966 International Covenant on Civil and Political Rights (ICCPR), which serves to operationalise the UDHR in tandem with the International Covenant on Economic, Social and Cultural Rights (ICESCR). If we approach these treatises from a political economy perspective, and see them as historicized applications of certain structures of power, then a history of colonialism, post-colonialism and economic globalisation can be observed.

The Berne Convention for the Protection of Literary and Artistic Works was the first international agreement to establish a set of common standards for copyright protection among its signatory states. The convention was adopted in Switzerland in 1886, after negotiations between the major European powers, and was the child of a colonial world order (Hemmungs Wirtén 2004; Ricketson and Ginsburg 2006; Balasz 2011; Fredriksson 2014; Homestead 2005). It was mostly a European initiative and the USA did not sign until 1989 (Balasz 2011; Fredriksson 2014; Homestead 2005). In order to form an international treaty that could include the USA and cater more to the needs of 'developing' countries, UNESCO adopted The Universal Copyright Convention in 1952. 
This became the first international copyright treaty to include USA, as well as a number of South American countries that were also not parties to the Berne Convention (Letterman 2001, 160).

In 1967 WIPO was formed as a specialized agency within the United Nations assigned to promote IPR globally and administrate the Berne Convention. In 1994 and 1996 WIPO passed its own two treaties, the WIPO Copyright Treaty and the WIPO Performance and Phonograms Treaty, attempting to complement the Berne Convention in a digital society (Hemmungs Wirtén 2004; Samuelson 1996).

When the General Agreement on Trade and Tariffs (GATT) was transformed into the World Trade Organization (WTO) in 1994, IPR was given an important role as the TRIPS agreement became one of its cornerstones. Drahos and Braithwaite have shown how representatives of predominantly American and European IP-industries actively used TRIPS to influence the international IPR agenda when they found it hard to impose their demands through WIPO which, being a UN agency, could not disregard the interest of 'developing' countries (Fredriksson 2012; Drahos and Braithwaite 2002). The TRIPS agreement borrowed rhetoric and content from the Berne Convention (Heath 2014), but redefined IPRs as a trade issue by incorporating it in the WTO structure, emphasizing free trade and economic globalization (Drahos and Braithwaite 2002; Hemmungs Wirtén 2004; Fredriksson 2012).

Applying a political economy perspective to IPR as a global legislative regime exposes how IPR has been inscribed in a wider geopolitical development. The internationalisation of copyright began in the late $19^{\text {th }}$ century as multilateral agreements between European powers that by default extend across large parts of the colonial world. At this stage copyright was still considered a predominantly cultural concern, focusing on promoting creativity and protecting the rights of authors. In the 1950s and 60s IPRs were brought onto the global governance agenda through the UCC and the formation of WIPO, reflecting an idea that a well-balanced IP regime that rewards IP-holders while acknowledging public interests can promote global development not only culturally but also socially and economically. The TRIPS agreement of 1994 in its turn represented a paradigmatic shift in international IPR-legislation in the sense that it redefined IPR from a cultural to a financial matter. As it caught the interest of WTO, IPRs became increasingly defined as a trade regulation and incorporated into an agenda of economic 
globalization. The international system of copyright, that comes across as a neutral and universal bundle of rights, is thus a culturally contingent and historically rooted framework for looking at creativity, authorship, and property that has been constructed by specific actors for specific reasons (Fredriksson 2014).

Relating intellectual property to the African Charter on Human and Peoples' Rights and UDHR might be alien to the conventional historiography of intellectual property, but IPRs might just as well be contextualised in relation to human rights as to economic treatises. Farida Shaheed $(2014 ; 2013)$, UN Special Rapporteur in the field of cultural rights (between 2009 and 2015) has worked to uncover the tensions between copyright and the right to culture. Under influence of Shaheed the UN Office of the High Commissioner for Human Rights (OHCHR) argues there is a conflict between these types of rights. Laurence Helfer points out that this approach assumes that strong IPR is incompatible with human rights as it undermines many human rights obligations, particularly regarding economic, social, and cultural rights (Helfer 2003, 48; see also Shaver and Sganga 2009, 14). This can involve anything from the possibility to take part in cultural activities or consume art on equal terms regardless of geographic and social position, through the access to education and textbooks, to basic material needs such as the access to life sustaining patent drugs.

On the other hand, the World Trade Organisation claims that IPR and human rights operate in coexistence, and hence without real conflict (Yu 2007, 709-710). This coexistence approach argues that the two clauses of Article 27 address the same basic question: 'defining the appropriate scope of private monopoly power that gives authors and inventors a sufficient incentive to create and innovate, while ensuring that the consuming public has adequate access to the fruits of their efforts' (Helfer 2003, 48). This however puts a particular responsibility on the state to strike a balance and prevent IPR from infringing too much on the citizen's right to public and equal access to knowledge and information, particularly in respect to marginalized groups that are usually disregarded in the law making process: 'the poor, the disadvantaged, racial, ethnic and linguistic minorities, women, rural residents' (Chapman 2001, cited in Helfer and Austin 2011, 77).

The coexistence approach presumes no intrinsic conflict between the sections of Article 27. The tension, however, is not so much how to resolve conflicting normative 
perspectives, but how to deal with the messy process when these ideas collide in practice. Where a strict enforcement of copyright legislation may be a way to follow Article 27(2) that concerns the right to the protection of one's moral and material interests, piracy may be a way to ensure the application of Article 27(1) that concerns the right to freely partake in cultural life.

\section{African implementations of a globalized copyright regime}

In Rethinking Intellectual Property: The Political Economy of Copyright in the Digital Era, YiJun Tian calls for a copyright policy, or a political economy of copyright, which can address the digital, knowledge divide that exists between 'developed' and 'developing' countries - even if this distinction itself is flawed and out-dated (Neuwirth 2013; Neuwirth 2016; De Beukelaer 2014). Such a copyright policy would promote what Tian calls a 'knowledge equilibrium': a balance in the different actors' possibilities to access and utilise knowledge to promote their own economic and social interests (Tian 2009). This global imbalance is situated within a colonial history where, for instance, African states have had a limited impact on the development on international copyright legislation. This section looks at how different African countries come into this development, paying particular attention to Ghana as a case study. As a starting point for this discussion we have constructed a table that gives an overview over when and how different countries joined the most important international copyright treatises and conventions. In addition, we have also included two of the most important human rights declarations for this continent. Exploring African countries' adoption of different treatise and declaration side by side, we have uncovered a historical timeline that connects the implementation of IP treatises throughout Africa to the continent's colonial and postcolonial past and present. 
Table 1. African implementations of IPR and Human Rights conventions

\begin{tabular}{|c|c|c|c|c|c|c|c|c|c|}
\hline & Berne & $\mathrm{UCC}^{\mathrm{iv}}$ & Rome & WIPO & WCT $^{\text {vii }}$ & WPPT & GAT & WTO/TRIPS & ICESCR \\
\hline & $\begin{array}{l}\text { Conventio } \\
\text { n }^{\text {iii }}(\mathbf{1 8 8 6})\end{array}$ & (1952) & $\begin{array}{l}\text { Conventi } \\
\text { on }^{\mathrm{v}} \\
\text { (1961) }\end{array}$ & $\begin{array}{l}\text { Convent } \\
\text { ion } \\
\text { vi(1967) }\end{array}$ & (1996) & $\begin{array}{l}\text { viii } \\
\text { (1996) }\end{array}$ & $\begin{array}{l}\mathrm{T}^{\mathrm{ix}} \\
(1947 \\
)\end{array}$ & 1995) & $(1966)^{x i}$ \\
\hline $\begin{array}{l}\text { Algeria } \\
\text { (1962) }\end{array}$ & $\begin{array}{l}\text { Accession } 1 \\
998\end{array}$ & $\begin{array}{l}\text { Accessi } \\
\text { on } \\
1973\end{array}$ & $\begin{array}{l}\text { Accessio } \\
\text { n } 2007\end{array}$ & $\begin{array}{l}\text { Signed } \\
1967 \\
\text { Ratified } \\
1975\end{array}$ & $\begin{array}{l}\text { Accessi } \\
\text { on } \\
20134\end{array}$ & $\begin{array}{l}\text { Accessi } \\
\text { on } \\
2013\end{array}$ & & & $\begin{array}{l}\text { Signed } \\
1968 \\
\text { Ratified } \\
1989\end{array}$ \\
\hline $\begin{array}{l}\text { Angola } \\
\text { (1975) }\end{array}$ & & & & $\begin{array}{l}\text { Accessio } \\
\text { n } 1985\end{array}$ & & & 1994 & 1996 & $\begin{array}{l}\text { Accession } \\
1992\end{array}$ \\
\hline $\begin{array}{l}\text { Benin } \\
\text { (1960) }\end{array}$ & $\begin{array}{l}\text { In force } \\
1960 \\
\text { Continued } \\
\text { application } \\
1961\end{array}$ & & & $\begin{array}{l}\text { Accessio } \\
\text { n } 1974\end{array}$ & $\begin{array}{l}\text { Accessi } \\
\text { on } \\
2006\end{array}$ & $\begin{array}{l}\text { Accessi } \\
\text { on } \\
2006\end{array}$ & 1963 & 1996 & $\begin{array}{l}\text { Accession } \\
1992\end{array}$ \\
\hline $\begin{array}{l}\text { Botswan } \\
a \\
\text { (1966) }\end{array}$ & $\begin{array}{l}\text { Accession } \\
1998\end{array}$ & & & $\begin{array}{l}\text { Accessio } \\
\text { n } 1998\end{array}$ & $\begin{array}{l}\text { Accessi } \\
\text { on } \\
2006\end{array}$ & $\begin{array}{l}\text { Accessi } \\
\text { on } \\
2004\end{array}$ & 1987 & 1995 & \\
\hline $\begin{array}{l}\text { Burkina } \\
\text { Faso } \\
\text { (1960) }\end{array}$ & $\begin{array}{l}\text { Accession } \\
1963\end{array}$ & & $\begin{array}{l}\text { Accessio } \\
\text { n } 1987\end{array}$ & $\begin{array}{l}\text { Accessio } \\
\text { n } 1975\end{array}$ & $\begin{array}{l}\text { Signed } \\
1996 \\
\text { Ratifie } \\
\text { d } 1999\end{array}$ & $\begin{array}{l}\text { Signed } \\
1996 \\
\text { Ratifie } \\
\text { d } 1999\end{array}$ & 1963 & 1995 & $\begin{array}{l}\text { Accession } \\
1999\end{array}$ \\
\hline $\begin{array}{l}\text { Burundi } \\
\text { (1962) }\end{array}$ & & & & $\begin{array}{l}\text { Accessio } \\
\text { n } 1976\end{array}$ & & & 1965 & 1995 & $\begin{array}{l}\text { Accession } \\
1990\end{array}$ \\
\hline $\begin{array}{l}\text { Camero } \\
\text { on } \\
\text { (1960) }\end{array}$ & $\begin{array}{l}\text { In force } \\
1960 \\
\text { Continued } \\
\text { application } \\
1964\end{array}$ & $\begin{array}{l}\text { Accessi } \\
\text { on } \\
1973\end{array}$ & & $\begin{array}{l}\text { Signed } \\
1967 \\
\text { Ratified } \\
1973\end{array}$ & & & 1963 & 1995 & $\begin{array}{l}\text { Accession } \\
1984\end{array}$ \\
\hline $\begin{array}{l}\text { Cape } \\
\text { Verde } \\
\text { (1975) }\end{array}$ & $\begin{array}{l}\text { Accession } \\
1997\end{array}$ & & $\begin{array}{l}\text { Accessio } \\
\text { n } 1997\end{array}$ & $\begin{array}{l}\text { Accessio } \\
\text { n } 1997\end{array}$ & & & & 2008 & $\begin{array}{l}\text { Accession } 1 \\
993\end{array}$ \\
\hline $\begin{array}{l}\text { Central } \\
\text { African } \\
\text { Republic } \\
\text { (1960) }\end{array}$ & $\begin{array}{l}\text { Accession } \\
1997\end{array}$ & & & $\begin{array}{l}\text { Signed } \\
1967 \\
\text { Ratified } \\
1978\end{array}$ & & & 1963 & 1995 & $\begin{array}{l}\text { Accession } \\
1981\end{array}$ \\
\hline
\end{tabular}




\begin{tabular}{|c|c|c|c|c|c|c|}
\hline $\begin{array}{l}\text { Chad } \\
(1960)\end{array}$ & $\begin{array}{l}\text { Accession } \\
1971\end{array}$ & & $\begin{array}{l}\text { Accessio } \\
\text { n } 1970\end{array}$ & 1963 & 1996 & $\begin{array}{l}\text { Accession } \\
1995\end{array}$ \\
\hline $\begin{array}{l}\text { Comoro } \\
s \\
(1975)\end{array}$ & $\begin{array}{l}\text { Accession } \\
2005\end{array}$ & & $\begin{array}{l}\text { Accessio } \\
\text { n } 2005\end{array}$ & & & $\begin{array}{l}\text { Signed } \\
1998\end{array}$ \\
\hline $\begin{array}{l}\text { Democr } \\
\text { atic } \\
\text { Republic } \\
\text { of the } \\
\text { Congo } \\
(1960)\end{array}$ & $\begin{array}{l}\text { In force } \\
1960 \\
\text { Continued } \\
\text { application } \\
1962\end{array}$ & $\begin{array}{l}\text { Accessio } \\
\text { n } 1962\end{array}$ & $\begin{array}{l}\text { Accessio } \\
\text { n } 1975\end{array}$ & & 1997 & $\begin{array}{l}\text { Accession } \\
1976\end{array}$ \\
\hline $\begin{array}{l}\text { Republic } \\
\text { of the } \\
\text { Congo } \\
(1960)\end{array}$ & $\begin{array}{l}\text { In force } \\
1960 \\
\text { Continued } \\
\text { application } \\
1962\end{array}$ & & $\begin{array}{l}\text { Accessio } \\
\text { n } 1975\end{array}$ & 1963 & 1997 & $\begin{array}{l}\text { Accession } \\
1981\end{array}$ \\
\hline $\begin{array}{l}\text { Djibouti } \\
\text { (1977) }\end{array}$ & $\begin{array}{l}\text { Accession } \\
2003\end{array}$ & & $\begin{array}{l}\text { Signed } \\
1967 \\
\text { Ratified } \\
1974\end{array}$ & 1994 & 1995 & $\begin{array}{l}\text { Accession } \\
2002\end{array}$ \\
\hline $\begin{array}{l}\text { Egypt } \\
(1922)\end{array}$ & $\begin{array}{l}\text { Accession } \\
1977\end{array}$ & & $\begin{array}{l}\text { Accessio } \\
\text { n } 1975\end{array}$ & 1970 & 1995 & $\begin{array}{l}\text { Signed } \\
1967 \\
\text { Ratified } \\
1982\end{array}$ \\
\hline $\begin{array}{l}\text { Equatori } \\
\text { al } \\
\text { Guinea } \\
\text { (1968) }\end{array}$ & $\begin{array}{l}\text { Accession } \\
1997\end{array}$ & & $\begin{array}{l}\text { Accessio } \\
\text { n } 1997\end{array}$ & & & $\begin{array}{l}\text { Accession } \\
1987\end{array}$ \\
\hline $\begin{array}{l}\text { Eritrea } \\
\text { (1993) }\end{array}$ & & & $\begin{array}{l}\text { Accessio } \\
\text { n } 1996\end{array}$ & & & $\begin{array}{l}\text { Accession } \\
2001\end{array}$ \\
\hline $\begin{array}{l}\text { Ethiopia } \\
\text { N/A }\end{array}$ & & & $\begin{array}{l}\text { Accessio } \\
\text { n } 1997\end{array}$ & & & $\begin{array}{l}\text { Accession } \\
1993\end{array}$ \\
\hline
\end{tabular}




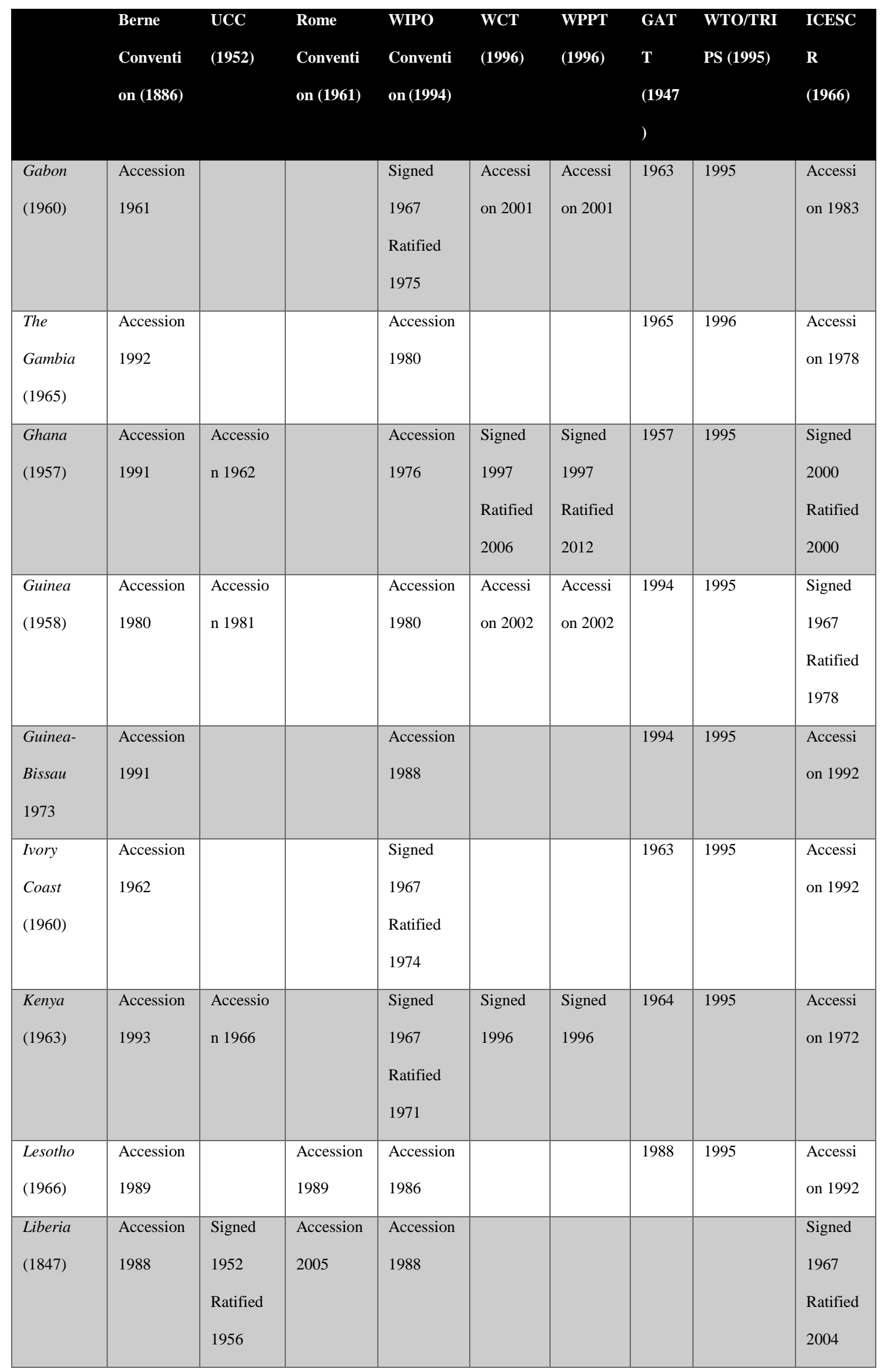




\begin{tabular}{|c|c|c|c|c|c|c|c|c|c|}
\hline $\begin{array}{l}\text { Libya } \\
\text { (1951) }\end{array}$ & $\begin{array}{l}\text { Accession } \\
1976\end{array}$ & & & $\begin{array}{l}\text { Accession } \\
1976\end{array}$ & & & & & $\begin{array}{l}\text { Accessi } \\
\text { on } 1970\end{array}$ \\
\hline $\begin{array}{l}\text { Madagasc } \\
\text { ar } \\
(1960)\end{array}$ & $\begin{array}{l}\text { In force } \\
1966 \\
\text { Continued } \\
\text { applicatio } \\
\text { n } 1966\end{array}$ & & & $\begin{array}{l}\text { Signed } \\
1967 \\
\text { Ratified } \\
1989\end{array}$ & $\begin{array}{l}\text { Accessi } \\
\text { on } 2014\end{array}$ & $\begin{array}{l}\text { Accessi } \\
\text { on } 2014\end{array}$ & 1963 & 1995 & $\begin{array}{l}\text { Signed } \\
1970 \\
\text { Ratified } \\
1971\end{array}$ \\
\hline $\begin{array}{l}\text { Malawi } \\
\text { (1964) }\end{array}$ & $\begin{array}{l}\text { Accession } \\
1991\end{array}$ & $\begin{array}{l}\text { Accessio } \\
\text { n } 1965\end{array}$ & & $\begin{array}{l}\text { Accession } \\
1970\end{array}$ & & & 1964 & 1995 & $\begin{array}{l}\text { Accessi } \\
\text { on } 1993\end{array}$ \\
\hline $\begin{array}{l}\text { Mali } \\
(1960)\end{array}$ & $\begin{array}{l}\text { In force } \\
1962 \\
\text { Continued } \\
\text { applicatio } \\
\text { n } 1962\end{array}$ & & & $\begin{array}{l}\text { Accession } \\
1982\end{array}$ & $\begin{array}{l}\text { Accessi } \\
\text { on } 2002\end{array}$ & $\begin{array}{l}\text { Accessi } \\
\text { on } 2001\end{array}$ & 1993 & 1995 & $\begin{array}{l}\text { Accessi } \\
\text { on } 1974\end{array}$ \\
\hline $\begin{array}{l}\text { Mauritani } \\
a \\
(1960)\end{array}$ & $\begin{array}{l}\text { Accession } \\
1972\end{array}$ & & & $\begin{array}{l}\text { Accession } \\
1976\end{array}$ & & & 1963 & 1995 & $\begin{array}{l}\text { Accessi } \\
\text { on } 2004\end{array}$ \\
\hline $\begin{array}{l}\text { Mauritius } \\
\text { (1968) }\end{array}$ & $\begin{array}{l}\text { Accession } \\
1989\end{array}$ & $\begin{array}{l}\text { In force } \\
1968 \\
\text { Successi } \\
\text { on } 1970\end{array}$ & & $\begin{array}{l}\text { Accession } \\
1976\end{array}$ & & & 1970 & 1995 & $\begin{array}{l}\text { Accessi } \\
\text { on } 1973\end{array}$ \\
\hline $\begin{array}{l}\text { Morocco } \\
\text { (1956) }\end{array}$ & $\begin{array}{l}\text { Accession } \\
1917\end{array}$ & $\begin{array}{l}\text { Accessio } \\
\text { n } 1970\end{array}$ & & $\begin{array}{l}\text { Signed } \\
1967 \\
\text { Ratified } \\
1971\end{array}$ & $\begin{array}{l}\text { Accessi } \\
\text { on } 2011\end{array}$ & $\begin{array}{l}\text { Accessi } \\
\text { on } 2011\end{array}$ & 1987 & 1995 & $\begin{array}{l}\text { Signed } \\
1977 \\
\text { Ratified } \\
1979\end{array}$ \\
\hline $\begin{array}{l}\text { Mozambiq } \\
\text { ue } \\
\text { (1975) }\end{array}$ & $\begin{array}{l}\text { Accession } \\
2013\end{array}$ & & & $\begin{array}{l}\text { Accession } \\
1996\end{array}$ & & & 1992 & 1995 & \\
\hline $\begin{array}{l}\text { Namibia } \\
\text { (1960) }\end{array}$ & $\begin{array}{l}\text { In force } \\
1990 \\
\text { Continued } \\
\text { applicatio } \\
\text { n } 1993\end{array}$ & & & $\begin{array}{l}\text { Accession } \\
1991\end{array}$ & $\begin{array}{l}\text { Signed } \\
1997\end{array}$ & $\begin{array}{l}\text { Signed } \\
1996\end{array}$ & 1992 & 1996 & $\begin{array}{l}\text { Accessi } \\
\text { on } 1994\end{array}$ \\
\hline $\begin{array}{l}\text { Niger } \\
\text { (1960) }\end{array}$ & $\begin{array}{l}\text { In force } \\
1960\end{array}$ & $\begin{array}{l}\text { Accessio } \\
\text { n } 1989\end{array}$ & $\begin{array}{l}\text { Accession } \\
1964\end{array}$ & $\begin{array}{l}\text { Signed } \\
1967 \\
\text { Ratified } \\
1971\end{array}$ & & & 1963 & 1996 & $\begin{array}{l}\text { Accessi } \\
\text { on } 1986\end{array}$ \\
\hline
\end{tabular}




\begin{tabular}{|c|c|c|c|c|c|c|c|c|c|}
\hline & $\begin{array}{l}\text { Continued } \\
\text { applicatio } \\
\text { n } 1962\end{array}$ & & & & & & & & \\
\hline $\begin{array}{l}\text { Nigeria } \\
\text { (1960) }\end{array}$ & $\begin{array}{l}\text { Accession } \\
1993\end{array}$ & $\begin{array}{l}\text { Accessio } \\
\text { n } 1961\end{array}$ & $\begin{array}{l}\text { Accession } \\
1993\end{array}$ & $\begin{array}{l}\text { Accession } \\
1995\end{array}$ & $\begin{array}{l}\text { Signed } \\
1997\end{array}$ & $\begin{array}{l}\text { Signed } \\
1997\end{array}$ & 1960 & 1995 & $\begin{array}{l}\text { Accessi } \\
\text { on } 1993\end{array}$ \\
\hline $\begin{array}{l}\text { Rwanda } \\
\text { (1962) }\end{array}$ & $\begin{array}{l}\text { Accession } \\
1983\end{array}$ & $\begin{array}{l}\text { Accessio } \\
\text { n } 1981\end{array}$ & & $\begin{array}{l}\text { Accession } \\
1983\end{array}$ & & & 1966 & 1996 & $\begin{array}{l}\text { Accessi } \\
\text { on } 1975\end{array}$ \\
\hline
\end{tabular}

\begin{tabular}{|c|c|c|c|c|c|c|c|c|c|}
\hline & $\begin{array}{l}\text { Berne } \\
\text { Conventio } \\
\text { n (1886) }\end{array}$ & $\begin{array}{l}\text { UCC } \\
(\mathbf{1 9 5 2 )})\end{array}$ & $\begin{array}{l}\text { Rome } \\
\text { Conventio } \\
\text { n (1961) }\end{array}$ & $\begin{array}{l}\text { WIPO } \\
\text { Conventio } \\
\text { n(1994) }\end{array}$ & $\begin{array}{l}\text { WCT } \\
\text { (1996) }\end{array}$ & $\begin{array}{l}\text { WPPT } \\
\text { (1996) }\end{array}$ & $\begin{array}{l}\text { GAT } \\
\text { T } \\
(1947 \\
)\end{array}$ & $\begin{array}{l}\text { WTO/TRIP } \\
\text { S (1995) }\end{array}$ & $\begin{array}{l}\text { ICESCR } \\
(1966)\end{array}$ \\
\hline $\begin{array}{l}\text { São } \\
\text { Tomé } \\
\text { and } \\
\text { Príncipe } \\
\text { (1975) }\end{array}$ & & & & $\begin{array}{l}\text { Accession } \\
1998\end{array}$ & & & & & $\begin{array}{l}\text { Signed } \\
1995\end{array}$ \\
\hline $\begin{array}{l}\text { Senegal } \\
\text { (1960) }\end{array}$ & $\begin{array}{l}\text { Accession } \\
1962\end{array}$ & $\begin{array}{l}\text { Accessio } \\
\text { n } 1974\end{array}$ & & $\begin{array}{l}\text { Signed } \\
1967 \\
\text { Ratified } \\
1968\end{array}$ & $\begin{array}{l}\text { Signed } \\
1997 \\
\text { Ratifie } \\
\text { d } 2002\end{array}$ & $\begin{array}{l}\text { Signed } \\
1997 \\
\text { Ratifie } \\
\text { d } 2002\end{array}$ & 1963 & 1995 & $\begin{array}{l}\text { Signed } \\
1970 \\
\text { Ratified } \\
1978\end{array}$ \\
\hline $\begin{array}{l}\text { Seychelle } \\
\text { s } \\
(1976)\end{array}$ & & & & $\begin{array}{l}\text { Accession } \\
1999\end{array}$ & & & & 2015 & $\begin{array}{l}\text { Accessio } \\
\text { n } 1992\end{array}$ \\
\hline $\begin{array}{l}\text { Sierra } \\
\text { Leone } \\
(1961)\end{array}$ & & & & $\begin{array}{l}\text { Accession } \\
1986\end{array}$ & & & 1961 & 1995 & $\begin{array}{l}\text { Accessio } \\
\text { n } 1996\end{array}$ \\
\hline $\begin{array}{l}\text { Somalia } \\
\text { (1960) }\end{array}$ & & & & $\begin{array}{l}\text { Accession } \\
1992\end{array}$ & & & & & $\begin{array}{l}\text { Accessio } \\
\text { n } 1990\end{array}$ \\
\hline $\begin{array}{l}\text { South } \\
\text { Africa } \\
\text { (1931) }\end{array}$ & $\begin{array}{l}\text { In force } \\
1928 \\
\text { Continued } \\
\text { application } \\
1928\end{array}$ & & & $\begin{array}{l}\text { Signed } \\
1967 \\
\text { Ratified } \\
1974\end{array}$ & $\begin{array}{l}\text { Signed } \\
1997\end{array}$ & $\begin{array}{l}\text { Signed } \\
1997\end{array}$ & 1948 & 1995 & $\begin{array}{l}\text { Signed } \\
1994 \\
\text { Ratified } \\
2015\end{array}$ \\
\hline $\begin{array}{l}\text { South } \\
\text { Sudan }\end{array}$ & & & & & & & & & \\
\hline $\begin{array}{l}\text { Sudan } \\
\text { (1956) }\end{array}$ & $\begin{array}{l}\text { Accession } \\
2000\end{array}$ & & & $\begin{array}{l}\text { Accession } \\
1973\end{array}$ & & & & & $\begin{array}{l}\text { Accessio } \\
\text { n } 1986\end{array}$ \\
\hline
\end{tabular}




\begin{tabular}{|c|c|c|c|c|c|c|c|c|c|}
\hline $\begin{array}{l}\text { Swazilan } \\
d \\
(1968)\end{array}$ & $\begin{array}{l}\text { Accession } \\
1998\end{array}$ & & & $\begin{array}{l}\text { Accession } \\
1988\end{array}$ & & & 1993 & 1995 & $\begin{array}{l}\text { Accessio } \\
\text { n } 2004\end{array}$ \\
\hline $\begin{array}{l}\text { Tanzania } \\
\text { (1964) }\end{array}$ & $\begin{array}{l}\text { Accession } \\
1994\end{array}$ & & & $\begin{array}{l}\text { Accession } \\
1983\end{array}$ & & & 1961 & 1995 & $\begin{array}{l}\text { Accessio } \\
\text { n } 1976\end{array}$ \\
\hline $\begin{array}{l}\text { Togo } \\
(1960)\end{array}$ & $\begin{array}{l}\text { Accession } \\
1975\end{array}$ & $\begin{array}{l}\text { Accessio } \\
\text { n } 2003\end{array}$ & $\begin{array}{l}\text { Accession } \\
2003\end{array}$ & $\begin{array}{l}\text { Accession } \\
1975\end{array}$ & $\begin{array}{l}\text { Signed } \\
1996 \\
\text { Ratifie } \\
\text { d } 2003\end{array}$ & $\begin{array}{l}\text { Signed } \\
1996 \\
\text { Ratifie } \\
\text { d } 2003\end{array}$ & 1964 & 1995 & $\begin{array}{l}\text { Accessio } \\
\text { n } 1984\end{array}$ \\
\hline $\begin{array}{l}\text { Tunisia } \\
\text { (1956) }\end{array}$ & $\begin{array}{l}\text { Signed } \\
1886 \\
\text { Ratified } \\
1887\end{array}$ & $\begin{array}{l}\text { Accessio } \\
\text { n } 1969\end{array}$ & & $\begin{array}{l}\text { Signed } \\
1967 \\
\text { Ratified } \\
1975\end{array}$ & & & 1990 & 1995 & $\begin{array}{l}\text { Signed } \\
1968 \\
\text { Ratified } \\
1969\end{array}$ \\
\hline $\begin{array}{l}\text { Uganda } \\
(1962)\end{array}$ & & & & $\begin{array}{l}\text { Accession } \\
1973\end{array}$ & & & 1962 & 1995 & $\begin{array}{l}\text { Accessio } \\
\text { n } 1987\end{array}$ \\
\hline $\begin{array}{l}\text { Zambia } \\
\text { (1964) }\end{array}$ & $\begin{array}{l}\text { Accession } \\
1991\end{array}$ & & & $\begin{array}{l}\text { Accession } \\
1977\end{array}$ & & & 1982 & 1995 & $\begin{array}{l}\text { Accessio } \\
\text { n } 1984\end{array}$ \\
\hline $\begin{array}{l}\text { Zimbabw } \\
e \\
(1980)\end{array}$ & $\begin{array}{l}\text { In force } \\
1980 \\
\text { Continued } \\
\text { application } \\
1981\end{array}$ & & & $\begin{array}{l}\text { Accession } \\
1981\end{array}$ & & & 1948 & 1995 & $\begin{array}{l}\text { Accessio } \\
\text { n } 1991\end{array}$ \\
\hline
\end{tabular}

As Table 1 shows, the concept and legal context of copyright is a remnant of colonial rule in most African countries, which was created and enacted without their consideration or contribution.

It is significant for this colonial history that only one of the states, Tunisia, signed and ratified the Berne Convention at the time when it was drawn up in 1886. Most other African countries joined the Berne Convention by accession, meaning that they agreed to an already existing treaty without taking part in the negotiations preceding it. Many of the former French colonies that gained independence in 1960 joined the Berne Convention by default, as they had been subject to the convention as colonial territories, and then implemented it into their new national legislation. In all of those cases the independent states declared a continued application within a few years.

Ghana joined by accession in 1991 . This makes it similar to many other African countries 
who all joined the Berne Convention in the late 1980s or early 90s. Ghana had been a subject to the convention through Britain's Imperial Copyright Act of 1911, which applied to the colonized Ghana until it gained independence in 1957. In 1961 Ghana passed its first national copyright law as a sovereign country, largely based on the colonial laws. It was eventually adapted to meet national needs as well as international requirement in the subsequent copyright acts of 1985 and 2005 (Boateng 2011).

The Universal Copyright Convention is not well represented in Africa. Only 15 out of 54 African countries are party to the UCC, compared to 44 African signatories to the Berne Convention. Apart from Liberia, which signed and ratified the UCC at the time when it was passed, all African countries have joined by accession or succession, in some cases but not always, shortly after independence. With the exception of Togo all of them joined before 1989, when USA acceded the Berne Convention. Ghana acceded the UCC in May 1962, only 5 years after its independence, but nearly 30 years before it joined the Berne Convention. This meant that Ghana, just like the USA, was bound by the UCC but not the Berne Convention for a long time. There is a similar pattern in a few other African countries. This could indicate that they were keen to have a copyright treaty with the USA, which would ensure their authors copyright protection in America.

As a contrast all African states except South Sudan have joined WIPO. In most cases they joined by accession in the 1970s, 80s or 90s, but nine of the countries signed and ratified the WIPO convention already in the 60s. Ghana joined by accession in 1976, which is fairly early. The WCT and the WPPT are however less represented and have only been joined by 15 African countries. Ghana signed both treatises in 1997 and ratified the WCT in 2006 and the WPPT in 2012. Ghana has also been influenced by WIPO's work to promote the protection of traditional knowledge, codified in the Model Provisions for National Laws on Protection of Expressions of Folklore against Illicit Exploitation and Other Prejudicial Actions which inspired Ghana to grant folklore protection under the copyright law of 1985 (Boateng 2011; Perlman 2011).

Today, 42 African countries are members of the WTO, which replaced GATT in 1995. Most of those made a seamless transition from GATT to WTO since Article XI(1) of the WTO Agreement states that all members of GATT were by default accepted as original members of the WTO, and consequently also parties to the TRIPS agreement. Ghana joined GATT in 1957, the same year as it gained independence, and became original 
member of WTO in 1995. WTO and TRIPS initiated a series of reforms that lead to the passing of the new national copyright law in 2005. In addition to the requirements from TRIPS the new copyright act maintained its strong emphasis on rights to musical works as well as the provisions on folklore introduced in 1985 (Boateng 2011).

By 2015, all African countries except South Sudan and Morocco had signed the African Charter of Human and People's Rights, and all except South Sudan were members of the UN and thus expected to respect the UDHR. We chose to look at the African countries' responses to the International Covenant on Economic, Social and Cultural Rights (ICESCR), which operationalized the UDHR in relation to the sphere of rights that interact most intimately with IP. Only three African countries have not approved ICESCR: Botswana, Mozambique and South Sudan. 39 countries have joined by accession over a fairly long period of time, stretching from the mid-1970s to early 2000s. Of the 12 countries that signed the ICESCR, a handful did so in the years immediately following its passing. Ghana signed and ratified both the ICESCR and the ICCPR in one stroke on September 7, 2000. When the UN in 2008 adopted an Optional Protocol to the ICESCR that established inquiry procedure for violations of these rights, Ghana signed the protocol on its first day of signature, 24 September 2009.

This section has shown that African states have, in most cases, been incorporated in global governmental structures dictated by (neo)colonial western powers. Consequently, in most cases, post-colonial states have been expected to implement international IPR treatises they have not themselves taken part in formulating. Table 1 also indicates that the inclusion of African states has been most effective when it comes to the implementation on the TRIPS agreement and the global trade agenda on which it relies, while WIPO has been less successful in implementing its treatises in Africa. The only instruments that are as well represented as the TRIPS agreement are the African Charter on Human and Peoples' Rights and the UNs Universal Declaration of Human Rights, which could potentially serve as counterweights to the IPR agenda imposed by the TRIPS agreement.

\section{'The Copyright Thing Doesn't Work Here? 'xii}

The protection of folklore relies more on WIPO provision than on TRIPS, which does not acknowledge traditional knowledge at all. This is a good example of the biases inherent in TRIPS. As Boateng $(2011,157)$ notes, patents on plants and human genetic material 
'are protected within TRIPS, while local and indigenous knowledge, such as those included in Ghanaian folklore, are not'. One of the arguments for not including traditional knowledge in TRIPS was that it would be hard to establish authorship to a resource that is usually collectively owned. This, however, did not stop TRIPS from acknowledging geographical indicators of origin (GI) - a right that is just as hard to attribute to individual authors but is of importance for many European business (Boyle 1996; Blakeney 2000). The IPR agenda set down in TRIPS thus protects the methods of appropriation used by western companies while it excludes traditional forms of ownership applied by local and indigenous groups in 'developing' countries.

This reflects what Boateng calls 'normalization of intellectual property law as a universal form and the structure of the current international regulatory regime' $(2011,16)$. This is a process where copyright takes precedence as the only model of regulating the circulation of knowledge and culture. The normalization of intellectual property underpins the polarisation between copyright and piracy in 'developing' countries, where copyright is assumed to promote economic and social development while piracy is believed to undermine it. It is precisely the political economy of this normalization that we call into question by focusing on the tension between copyright and cultural rights. If GHAMRO's interventions are meant to merely 'clean up' piracy and other irregularities in copyright enforcement, what implications does this have for cultural rights?

\section{Balancing Article 27: A Cultural Rights Approach}

The post-colonial imposition of (colonial era) intellectual property legislation across Africa, in combination with the tendency not to renegotiate post-colonial treatises upon declaration of independence has given countries insufficient leeway to develop their own copyright frameworks. The result is that the existing copyright legislation either does not work, or is unable to incorporate existing socio-economic practices (Boateng 2011). This means that it is difficult to balance the two elements of Article 27. Yet beyond the global imbalances, tensions between copyright and cultural rights arise in part from the different standing of the different 'generations' of human rights (Oguamanam 2006).

Overall, human rights can be divided in three generations. The first generation comprises civil and political rights (Articles 3 to 21 of the 1948 UDHR and the 1966 ICCPR). These are meant as ways to limit the power of the state over its citizens. The second generation 
includes economic and social rights (Articles 22 to 28 of the 1948 UDHR, and the 1966 ICESCR). These articles make the guarantee of human rights enforcements obligations of the state. And the third generation are environmental, cultural and developmental rights (1972 Stockholm Declaration of the United Nations Conference on the Human Environment, the 1992 Rio Declaration on Environment and Development). The third generation of rights are more difficult to enforce, as they generally fall beyond the scope of the nation and their objectives are more difficult to pin down in legally binding documents. The role of the state is more ambiguous because of the grand aims that fall under the umbrella of third generation rights. ${ }^{\text {xiii }}$

Janusz Symonides argues that cultural rights tend to be neglected, 'underdeveloped' and less likely to be addressed in national policies and legislation than political, economic, and social rights (Symonides 1998, 559). This further exemplifies the unbalanced enforcement of Article 27; while national legislation as well as international treatises and conventions provide extensive protection for authors' 'moral and material interests', the 'right freely to participate in the cultural life of the community' lacks any comparative legal enforcement; a paradox that resonates in the ICESCR. These conventions and treatises all include reference to the right to access culture and the right to benefit from the material and moral interest emanating from creation and invention.

(1) Everyone has the right freely to participate in the cultural life of the community, to enjoy the arts and to share in scientific advancement and its benefits.

(2) Everyone has the right to the protection of the moral and material interests resulting from any scientific, literary or artistic production of which he is the author. Universal Declaration of Human Rights, Article 27

1. The States Parties to the present Covenant recognize the right of everyone:

(a) To take part in cultural life;

(b) To enjoy the benefits of scientific progress and its applications;

(c) To benefit from the protection of the moral and material interests resulting from any scientific, literary or artistic production of which he is the author.

2. The steps to be taken by the States Parties to the present Covenant to achieve the full realization of this right shall include those necessary for the conservation, the development and the diffusion of science and culture.

3. The States Parties to the present Covenant undertake to respect the freedom indispensable for scientific research and creative activity.

4. The States Parties to the present Covenant recognize the benefits to be derived from the encouragement and development of international contacts and co-operation in the scientific and cultural fields.

International Covenant on Economic, Social and Cultural Rights, Article 15

The African Charter on Human and Peoples' Rights (1981), however, does not contain 
the paradox to which we refer above. This Charter makes explicit reference to participation, but not to the right to protection of moral and material interests emanating from the creation of cultural expressions:

1. Every individual shall have the right to education

2. Every individual may freely take part in the cultural life of his community.

3 . The promotion and protection of morals and traditional values recognized by the community shall be the duty of the State.

African Charter on Human and Peoples' Rights, Article 17

The African Charter thus favours participation over remuneration. It thereby addresses primarily the rights that are non-transferable, and not the (transferable) right to material interests. This implies a primacy of cultural rights (as access and participation) over copyright. But it equally implies a neglect of creative workers' rights. Yet the actual focus on legal orthodoxy regarding copyright legislation and enforcement is both limited in its effectiveness (as historical evidence suggests that piracy is curtailed by adapting industry practices rather than by suppressing them through legal means, see e.g. Kernfeld 2011) and limiting in the state's obligation to ensure 'the right of everyone to take part in cultural life' as the ICESCR stipulates. Lea Shaver and Caterina Sganga (2009, 6-9) unpack this right by detailing what its different elements mean in practice. They argue that 'cultural life' refers to both 'ways of life' and 'cultural expressions,' while:

The right to 'take part' in culture consists in the ability to consume and to create, individually and with others. Culture exists to be shared and to inhabit a culture is to contribute to it. To take part in cultural life implies the ability to access, enjoy, engage with and extend the cultural inheritance, to enact, wear, perform, produce, apply, interpret, read, modify, extend and remix; to manifest, interact, share, repeat, reinterpret, translate, critique, combine, and transform (Shaver and Sganga 2009, 9).

Finally, 'everyone,' as stipulated in the ICESCR includes all women and men, irrespective of cultural, ethnic, social, or political background. Shaver and Sganga (2009, 10) do stress that the universal validity of Article 15 of the ICESCR means that there should be no 'special rights for a class of professional authors' at the expense of amateurs and audiences. The broad articulation of participation and creation beyond the ideal of individual authorship explains the tensions that exist in practice. Boatema Boateng argues that:

To the extent that the copyright thing doesn't work in Ghana, it is because intellectual property law is part of a normative modernization framework that leaves very little space for alternative modes of social, economic, political, and legal organization. It is also because the Ghanaian state has not fully explored those spaces that do exist 
for considering those alternatives and infusing them into policymaking. (Boateng 2011, 166)

Moreover, when debate around the implementation of copyright legislation and enforcement takes place, this occurs within the legal framework that remains unchallenged and intact (Boateng 2011, 177).

The modernist logic of copyright challenges both the 'morals and traditional values recognized by the community' and the right of 'every individual [to] freely take part in the cultural life of his community' as they ought to be protected by the African Charter on Human and Peoples' Rights. While the results of stricter copyright protection may be good for some people (and GDP numbers, as trade in copyrighted goods would be recorded in official statistics), it may not benefit the population as a whole. It thus favours the enforcement of orthodoxy of copyright over the application of the African charter or the balancing of Article 27 of the UDHR. The remaining question, which the next section addresses, is if attempts to enforce copyright in Ghana exacerbate tensions between different regimes of rights bestowed on citizens. What can be done to mitigate the expansion of copyright protection at the expense of cultural rights protection?

\section{Conclusions: Beyond Legal Orthodoxy?}

This article has shown how the push to strictly enforce copyright legislation in Ghana builds on a narrow framing of cultural rights. These include, as stipulated in Article 27 of the UDHR, both the right to the 'moral and material interests' emanating from creations and 'to participate in the cultural life of the community [and] to enjoy the arts.' Without much debate, the Ghanaian attempt to enforce copyright silently undermines cultural rights. Yet, the socio-cultural implications of a legal divide between author and audience has particular (i.e. culturally contingent) roots in the West:

The vast majority of the world's population fails to access the flows of technology, media, goods and ideas according to the dominant logic of property set as 'modern' standard. This standard ... has a distinct local history; it basically evolved from British utilitarian legal models and German idealist notions of personal authorship, but travelled quickly across the Atlantic and beyond. (Eckstein and Schwarz 2014b, $1-2)$

The legalistic intellectual property framework attained a global reach during the heyday of colonialism. Which means that while colonies had no say in the creation of these rules 
and regulations, they were subjected to them.

Following Farida Shaheed (2014; 2013), we argue that cultural rights suffer from neglect because of the creeping (and at times rampant) extension of intellectual property rights. We have made the case that while multiple legal texts call for a balance between creators' and audiences' rights, the push to eradicate piracy, and the global implementation of a biased IP-regime, disproportionally benefits the former to the detriment of the latter.

Moreover, the African Charter favours a reading of cultural rights as essentially based on education, community, and values, not monetary gain. The inaction of the state or their inability to enforce copyright legislation can be said to foster the spread of piracy. Yet, there are indications that piracy and limited copyright regimes in fact allows content creators to earn an income while providing wider access to culture (Lobato and Thomas 2011; Eckstein and Schwarz 2014a).

In summary, we argue that a postcolonial engagement with the tension within Article 27 is needed to resolve this in an equitable manner. This necessity emanates from the colonial legacy of copyright agreements and legislation, the overlapping praxis of piracy and legitimate business, and the need to respect cultural rights as important part of human rights instruments. We conclude that the shifts from the informal to the formal, and from the illegal to the legal through the attempt to eradicate of piracy is central to industry development strategies in Ghana and beyond.

Given the tension between copyright and human rights, GHAMRO's intervention of 'cleaning up' piracy is not a neutral or merely technical exercise. It is rather a deeply political act that favours the rights owners over audiences, and remuneration over participation. But 'if history provides one leg on which the deconstruction of copyright law can stand, then the concept of culture provides the other' (Fredriksson 2014, 1041). It is in this context that looking beyond the alleged conditio sine qua non of orthodox copyright legislation and enforcement can be seen as way to make authors and creators benefit from the fruit of their work while ensuring participation. While artists, rights holders, lawyers, and scholars have their say in the above debate, the Ghanaian (and, mutatis mutandis, African) audiences are notably absent. Most of all, pirates' voices are very rare in these debates. This prompts the question: can the pirate speak ? ${ }^{\mathrm{xiv}}$ The direct engagement with pirates by Tade and Akinleye (2012) is a rare piece of research that 
gives pirates voice. This makes it difficult to gauge at a more general level what pirates have to say. Yet pirates deserve a legitimate voice in a debate as they have historically been drivers of innovation (Kernfeld 2011), much like users of (illegal) digital media need to have a say too (Edwards et al. 2015).

This article challenges how dominant copyright frames piracy in 'developing' economies as a destructive and illegal practice that grows out of these countries' lack of economic, social and cultural development. By applying a political economy perspective on IPR it discusses how local implementations of global IPR agreements can be an extension of a (neo)colonial practice. From that viewpoint, the article has explored the role of piracy in African countries, hoping to contribute to a more nuanced understanding of copyright and piracy in Africa. We have thus situated copyright and piracy within a larger structure of global power relations that fall under human rights instruments. Although it is impossible to speak for absent audiences and pirates we hope that this perspective can contribute to destabilising those hegemonic discourses that have not only marginalised them economically and politically, but also culturally.

\section{References}

Balasz, Bodó. 2011. "Coda: A Short History of Book Piracy." In Media Piracy in Emerging Economies, edited by Joe Karaganis, 399-413. New York, NY: Social Science Research Council.

Bettig, Ronald V. 1996. Copyrighting Culture: The Political Economy of Intellectual Property. Critical Studies in Communication and in the Cultural Industries. Boulder, CO: Westview Press.

Blakeney, Michael. 2000. "The Protection of Traditional Knowledge under Intellectual Property Law.” European Intellectual Property Review 22 (6): 251-261.

Boateng, Boatema. 2011. The Copyright Thing Doesn't Work Here: Adinkra and Kente Cloth and Intellectual Property in Ghana. Minneapolis, MN: University of Minnesota Press.

Boyle, James. 1996. Shamans, Software, and Spleens: Law and the Construction of the Information Society. Cambridge, Mass: Harvard University Press.

Boyle, James. 2008. The Public Domain: Enclosing the Commons of the Mind. New Haven: Yale University Press.

Collins, John. 2006. "Copyright, Folklore and Music Piracy in Ghana." Critical Arts 20 (1): 158-170. doi:10.1080/02560040608557784.

De Beukelaer, Christiaan. 2014. "Creative Industries in 'developing' Countries: Questioning Country Classifications in the UNCTAD Creative Economy Reports." Cultural Trends 23 (4).

De Beukelaer, Christiaan. 2015. Developing Cultural Industries: Learning from the Palimpsest of Practice. Amsterdam: European Cultural Foundation. 
De Beukelaer, Christiaan. 2017. "Postcolonial Piracy: Media Distribution and Cultural Production in the Global South." Cultural Studies 31 (4): 604-607. doi:10.1080/09502386.2016.1167931.

Drahos, Peter, and John Braithwaite. 2002. Information Feudalism: Who Owns the Knowledge Economy? Abingdon: Earthscan.

Duxbury, Nancy, Anita Kangas, and Christiaan De Beukelaer. 2017. "Cultural Policies for Sustainable Development: Four Strategic Paths.” International Journal of Cultural Policy 23 (2).

Eckstein, Lars, and Anja Schwarz, eds. 2014a. Postcolonial Piracy: Media Distribution and Cultural Production in the Global South. London; New York, NY: Bloomsbury.

Eckstein, Lars, and Anja Schwarz. 2014b. "Introduction: Towards a Postcolonial Critique of Modern Piracy." In Postcolonial Piracy: Media Distribution and Cultural Production in the Global South, edited by Lars Eckstein and Anja Schwarz, 1-25. Theory for Global Age. London; New York, NY: Bloomsbury.

Edwards, L., B. Klein, D. Lee, G. Moss, and F. Philip. 2015. “'Isn't It Just a Way to Protect Walt Disney's Rights?': Media User Perspectives on Copyright." New Media \& Society 17 (5): 691-707. doi:10.1177/1461444813511402.

Fredriksson, Martin. 2012. "Piracy, Globalisation and the Colonisation of the Commons." Global Media Journal - Australian Edition 6 (1).

Fredriksson, Martin. 2014. "Copyright Culture and Pirate Politics." Cultural Studies 28 (5-6): 1022-1047. doi:10.1080/09502386.2014.886483.

GhanaWeb. 2012. "GHAMRO Taskforce Raids Music Pirates." Ghanaweb. http://www.ghanaweb.com/GhanaHomePage/NewsArchive/artikel.php?ID=233 303.

Golding, Peter, and Graham Murdock, eds. 1997. The Political Economy of the Media. International Library of Studies in Media and Culture 2. Cheltenham ; Brookfield, VT: Edward Elgar.

Helfer, Laurence R. 2003. "Human Rights and Intellectual Property: Conflict or Coexistence." Minnesota Intellectual Property Review 5 (1): 47-61.

Helfer, Laurence R., and Graeme W. Austin. 2011. Human Rights and Intellectual Property: Mapping the Global Interface. Cambridge; New York: Cambridge University Press.

Hemmungs Wirtén, Eva. 2004. No Trespassing: Authorship, Intellectual Property Rights, and the Boundaries of Globalization. Studies in Book and Print Culture. Toronto ; Buffalo: University of Toronto Press.

Hesmondhalgh, David, Kate Oakley, and David Lee. 2015. Culture, Economy and Politics: The Case of New Labour. New Directions in Cultural Policy Research. Basingstoke: Palgrave Macmillan.

Homestead, Melissa J. 2005. American Women Authors and Literary Property, 18221869. Cambridge ; New York: Cambridge University Press.

Karaganis, Joe, ed. 2011. Media Piracy in Emerging Economies. New York, NY: Social Science Research Council.

Kernfeld, Barry Dean. 2011. Pop Song Piracy: Disobedient Music Distribution since 1929. Chicago, IL: University of Chicago Press.

Larkin, Brian. 2005. "Nigerian Video: The Infrastructure of Piracy." Politique Africaine 100: 146-164.

Larkin, Brian. 2008. Signal and Noise: Media, Infrastructure, and Urban Culture in Nigeria. Durham: Duke University Press. 
Lessig, Lawrence. 2004. Free Culture: How Big Media Uses Technology and the Law to Lock down Culture and Control Creativity. New York, NY: Penguin Press.

Letterman, G. Gregory. 2001. Basics of International Intellectual Property Law. Ardsley, NY: Transnational Publishers.

Lobato, Ramon. 2010. "Creative Industries and Informal Economies: Lessons from Nollywood." International Journal of Cultural Studies 13 (4): 337-354. doi:10.1177/1367877910369971.

Lobato, Ramon, and Julian Thomas. 2011. "The Business of Anti-Piracy: New Zones of Enterprise in the Copyright Wars." International Journal of Communication forthcoming.

MacNeill, Kate. 2015. “Good Copyright Citizenship': Intellectual Property, Trade and Diplomacy." International Journal of Cultural and Creative Industries 2 (3): 3243.

MUSIGA, Government of Ghana, The World Bank, and KPMG. 2015. A Comprehensive Study of the Music Sector in Ghana. Accra: Musicians Union of Ghana.

Neuwirth, Rostam Josef. 2013. "Global Governance and the Creative Economy: The Developing versus Developed Country Dichotomy Revisited." Frontiers of Legal Research 1 (1): 127-144.

Neuwirth, Rostam Josef. 2016. "Global Law and Sustainable Development: Change and the 'Developing-Developed Country' Terminology." The European Journal of Development Research, October. doi:10.1057/s41287-016-0067-y.

Oguamanam, Chidi. 2006. International Law and Indigenous Knowledge: Intellectual Property, Plant Biodiversity, and Traditional Medicine. Toronto: University of Toronto Press.

Perlman, Marc. 2011. "From 'Folklore' to 'Knowledge' in Global Governance: On the Metamorphoses of the Unauthored." In Making and Unmaking Intellectual Property: Creative Production in Legal and Cultural Perspective, edited by Mario Biagioli, Peter Jaszi, and Martha Woodmansee, 115-132. Chicago: University of Chicago Press.

Ricketson, Sam, and Jane C. Ginsburg. 2006. International Copyright and Neighbouring Rights: The Berne Convention and Beyond. 2nd ed. Oxford; New York: Oxford University Press.

Samuelson, Pamela. 1996. "The U.S. Digital Agenda at WIPO." Virginia Journal of International Law 37: 369-440.

Shaheed, Farida. 2013. Report of the Special Rapporteur in the Field of Cultural Rights, The Right to Freedom of Artistic Expression and Creativity. A/HRC/23/34. Geneva: UNHCR.

Shaheed, Farida. 2014. Copyright Policy and the Right to Science and Culture. Human Rights Council, Twenty-eighth session GE.14-24951. New York: Unmited Nations General Assembly.

Shaver, Lea, and Caterina Sganga. 2009. "The Right to Take Part in Cultural Life: Copyright and Human Rights." Yale Faculty Scholarship Series Paper 23: 1-24.

Shipley, Jesse Weaver. 2013. Living the Hiplife: Celebrity and Entrepreneurship in Ghanaian Popular Music. Durham, NC: Duke University Press.

Smiers, Joost. 2000. "The Abolition of Copyright: Better for Artists, Third World Countries and the Public Domain." International Communication Gazette 62 (5): 379-406. doi:10.1177/0016549200062005003.

Smiers, Joost. 2008. "Creative Improper Property: Copyright and the Non-Western World." Third Text 22 (6): 705-717. doi:10.1080/09528820802652474. 
Spivak, Gayatri C. 1988. "Can the Subaltern Speak?” In Marxism and the Interpretation of Culture, edited by Cary Nelson and Lawrence Grossberg, 271-313. Urbana, IL: University of Illinois Press.

Sundaram, Ravi. 2009. Pirate Modernity: Delhi's Media Urbanism. London ; New York: Routledge.

Symonides, Janusz. 1998. "Cultural Rights: A Neglected Category of Human Rights." International Social Science Journal 50 (158): 559-572. doi:10.1111/14682451.00168.

Tade, Oludayo, and Babatunde Akinleye. 2012. "We Are Promoters Not Pirates': A Qualitative Analysis of Artistes and Pirates on Music Piracy in Nigeria." International Journal of Cyber Criminology 6 (2): 1014-1029.

Tian, YiJun. 2009. Re-Thinking Intellectual Property: The Political Economy of Copyright Protection in the Digital Era. Routledge-Cavendish Research in Intellectual Property. London; New York: Routledge-Cavendish.

UNCTAD, and UNDP. 2008. Creative Economy Report 2008: The Challenge of Assessing the Creative Economy: Towards Informed Policy-Making. UNCTAD/DITC/2008/2. Geneva: United Nations.

UNCTAD, and UNDP. 2010. Creative Economy Report 2010: Creative Economy: A Feasible Development Option. UNCTAD/DITC/TAB/2010/3. Geneva: United Nations.

Yu, Peter K. 2007. "Ten Common Questions about Intellectual Property and Human Rights.” Georgia State University Law Review 23 (4): 709-754.

\footnotetext{
i While Joost Smiers (2000; 2008) argues that it would be in the interest of 'developing' countries to dismiss copyright as a whole, as it would benefit content creators at the expense of cultural conglomerates, we take a less radical approach to copyright.

ii These reports resulted from UK engagement with cultural and creative industries as drivers of urban regeneration and regional development (see e.g. Hesmondhalgh, Oakley, and Lee 2015).

iii Source: WIPO: http://www.wipo.int/treaties/en/ShowResults.jsp?lang=en\&treaty_id=15

iv Source: WIPO: http://www.wipo.int/wipolex/en/other_treaties/parties.jsp?treaty_id=208\&group_id=22

${ }^{v}$ Source WIPO: http://www.wipo.int/treaties/en/ShowResults.jsp?lang=en\&treaty_id=17

${ }^{v i}$ Source: WIPO: http://www.wipo.int/treaties/en/ShowResults.jsp?\&treaty_id=1

vii Source WIPO: http://www.wipo.int/treaties/en/ShowResults.jsp?lang=en\&treaty_id=16

viii Source WIPO: http://www.wipo.int/treaties/en/ShowResults.jsp?lang=en\&treaty id=20

ix Source WTO: https://www.wto.org/english/thewto e/gattmem e.htm

${ }^{x}$ Source WTO: https://www.wto.org/english/thewto e/whatis e/tif e/org6 e.htm

${ }^{x i}$ Source UN: http://indicators.ohchr.org/ \&

https://www1.umn.edu/humanrts/research/ratification-tanzania.html

xii We have borrowed the title of this section from Boatema Boateng's insightful book on the challenges of matching copyright regimes and cultures of production in Ghana (Boateng 2011).

xiii Third generation rights are complex, as they often include elements that extend beyond the territorial sovereignty of the state; the issue is global, but the social contract of the polis is limited by the (nation) state. Addressing these global issues is moreover difficult, because of the lack of congruence between the imagined community of the nation-state and the global community that is confronted with issues like climate change. A possible resolution lies in
} 
the fostering of an 'imagined humanity', at least at some levels (Duxbury, Kangas, and De Beukelaer 2017).

xiv This paraphrases Gayatri Chakravorty Spivak's (1988) seminal postcolonial critique, 'can the subaltern speak?' (See also De Beukelaer 2017). 